\title{
JAG1 Gene
}

National Cancer Institute

\section{Source}

National Cancer Institute. AAG1 Gene. NCI Thesaurus. Code C75613.

This gene may be involved in hematopoiesis. 